Acta Biologica Plantarum Agriensis 5(1): 28 (2017) ISSN 2061-6716 (Print), 2063-6725 (Online) http://abpa.ektf.hu/
DOI:10.21406/abpa.2017.5.1.28

$4^{\text {th }}$ CC 2017 Abstract Plenary lecture

EFFECT OF FOREST MANAGEMENT ON BRYOPHYTE COMMUNITIES - A REVIEW Az erdőgazdálkodás hatása a mohaközösségekre - áttekintés

\title{
Péter ÓDOR
}

MTA Centre for Ecological Research, Institute of Ecology and Botany, H-2163 Vácrátót, Alkotány u. 2-4.; e-mail: odor.peter@okologia.mta.hu

Bryophytes are related to the available substrates within the forest as open soil, rock outcrops, trunks and dead wood. As poikilohydric organisms, they are very sensitive to air humidity conditions. In deciduous forest, litter layer inhibit the establishment of a bryophyte layer, terricolous species are related to microdisturbances. Epilithic bryophytes are sensitive to air humidity and dead wood accumulation beside rock surface availability. Epiphytic communities are determined mainly by tree species composition and presence of large trees. Dead wood inhabiting assemblages deteriorated in managed forest landscape because of limiting substrate (dead wood) availability. They show a clear succession during decay resulting that the continuity of dead wood of different decay stages and presence of large logs are necessary for their maintenance. Many dispersal limited epiphyte and epixylic species are influenced by forest connectivity and the temporal continuity of the appropriate substrate on landscape scale. They are very sensitive to microclimate determining structural elements like presence of secondary canopy, canopy gaps, shrub layer and presence of wetlands within the forests. Although epiphytic and epixylic assemblages are studied separately they belong to the same wood inhabiting bryophyte community related to the development and decomposition of trees as an example of primary succession. Because of the substrate and microclimate limitations of bryophytes, forest management that maintain a continuous forest cover, presence and diversity of dead wood as well as veteran trees can provide their long term sustainability. 